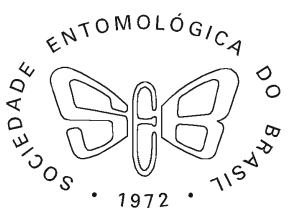

\title{
Geographical Distribution of Schizotetranychus hindustanicus and Associated Mites in Roraima, Brazil
}

\author{
FL Figueirêdo ${ }^{1}$, EG Fidelis ${ }^{2} \odot$, RS Pereira ${ }^{3}$, JC Santos ${ }^{3}$, M NegrinI $^{4}$, DC Oliveira ${ }^{1}$, GJ Moraes ${ }^{3}$ \\ ${ }^{1}$ Instituto Federal de Educação, Ciência e Tecnologia de Roraima, Boa Vista, Brasil \\ ${ }^{2}$ Embrapa Roraima, Boa Vista, Brasil \\ ${ }^{3}$ Escola Superior de Agricultura "Luiz de Queiroz", Univ de São Paulo, Piracicaba, Brasil \\ ${ }^{4}$ Univ Federal de Roraima, Boa Vista, Brasil
}

\section{Keywords}

Quarantine pest, Citrus spp., Hindustan citrus mite, Amblyseius aerialis

\section{Correspondence}

EG Fidelis, Embrapa Roraima, Boa

Vista, Brasil; elisangela.fidelis@gmail.com

Edited by Pedro Takao Yamamoto - ESALQ/ USP

Received 21 February 2019 and accepted 1 July 2019

(C) Sociedade Entomológica do Brasil 2019

\begin{abstract}
The Hindustan citrus mite, Schizotetranychus hindustanicus Hirst (Acari: Tetranychidae), is a quarantine pest present in the state of Roraima, Brazil. This mite, which was described in India in 1924, was reported in 2002 in Venezuela and spread to Roraima, where it was reported in 2008, and to Colombia, where it was reported in 2010. Its possible spread to other regions of Brazil is a threat to Brazilian citriculture. This study reports the current distribution of $S$. hindustanicus and potential predators of this pest and other mites associated with citrus in Roraima. A survey was conducted in August and September 2015 in the 15 municipalities of the state. In each municipality, orchards and citrus plants in backyards and public areas along highways and in urban areas were sampled. Samples of leaves and fruits were collected to identify the mite and its natural enemies. Schizotetranychus hindustanicus was found in all 15 municipalities in the state of Roraima. In total, 308 associated mites were found, with S. hindustanicus being the most abundant phytophagous mite, followed by Brevipalpus yothersi Baker. Amblyseius aerialis (Muma) was the most abundant predator, followed by Iphiseiodes zuluagai Denmark and Muma and Euseius concordis (Chant). The broad dispersal of S. hindustanicus in Roraima increases the risks of this pest reaching the main citrus-producing regions in Brazil.
\end{abstract}

\section{Introduction}

The Hindustan citrus mite, Schizotetranychus hindustanicus Hirst (Acari: Tetranychidae), was described from specimens collected from citrus trees in India in 1924 (Hirst 1924). For more than 80 years, this mite was known only from this region, where it has never been reported as a pest. In 2002, this mite was reported in Venezuela (Quirós and Geraud-Pouey 2002); in 2008, in Boa Vista, Roraima, Brazil (Navia \& Marsaro Jr 2010); and, in 2010, in northern Colombia (Mesa-Cobo 2010). In 2010, it was also reported in Iran (Sheikholeslam-Zadeh \& Sadeghi-Nameghi 2010). In all cases, the incidence was observed in citrus.
The characteristic sign of the incidence of $S$. hindustanicus is the formation of whitish erinea of 1 to $3 \mathrm{~mm}$ in diameter, forming webs on the leaves and fruits (Navia \& Marsaro Jr 2010). The different developmental stages of the mite, which discolor the plant tissue while feeding, are found under these webs. The erinea initially appear along the ribs on the adaxial surface of leaves and then spread to the entire adaxial and abaxial leaf surfaces and to the surface of the fruits. The attacked citrus leaves and fruits become silvery and hardened (Quirós \& Geraud-Poney 2002, Navia \& Marsaro Jr 2010).

In Venezuela and Roraima, high infestations of S. hindustanicus have been observed (Quirós \& Geraud- 
Poney 2002, Navia \& Marsaro Jr 2010), causing a reduction in the commercial value of the fruit due to esthetic damage, although a negative effect on fruit production cannot be ruled out. In Venezuela, the mite has been reported infesting Tahiti lemon, lime, tangerine, lemon, and sweet orange (Quirós \& Dorado 2005, Nienstaedt and Marcano 2009). In Brazil, S. hindustanicus has been observed in Tahiti lemon, Rangpur lime, Ponkan mandarin, Valencia orange, and Murcott tangor (Navia \& Marsaro Jr 2010). In India, the mite also has been reported infesting coconut, acacia, neem, chinaberry, and sorghum (Cherian 1931; Gupta \& Gupta 1994; Migeon \& Dorkeld 2018). Although infestations of $S$. hindustanicus have only been observed in citrus in South America (Ferragut et al 2013), in experiments conducted in Roraima, the mite had developed in neem plants for some generations after artificial infestation (Fantine 2011).

In Brazil, S. hindustanicus presently is considered a quarantine pest $(A 2)$, reported thus far only in the state of Roraima. In a survey conducted in 2010, the mite was found only in the municipalities of Boa Vista, Bonfim, and Cantá (Fantine 2011). The recommended legislative measures to avoid the spread of this mite to other Brazilian states are washing, brushing, and waxing of fruits destined for sale in pest-free states, as well as a ban on the transit of seedlings from infested areas (Mapa 2012). The dissemination of this mite in Brazil could cause serious impacts to citriculture due to damages, increase production costs with pest control, and possibly impose phytosanitary barriers to the international trade of fresh fruits.

Brazil is one of the world's largest producers of citrus and the largest exporter of orange juice. The annual Brazilian production of citrus fruits reached 14 million tons in 2017 (IBGE 2018). The export of orange juice in that year was more than one million tons, corresponding to US\$1.8 billion (Citros-BR 2018). In addition, the export of fresh lemons and oranges has increased, with that of Tahiti lemon corresponding to more than 60,000 (Boteon 2007) and that of orange to more than 27,000 (Citrus-BR 2018) tons per year. The largest citrus production is concentrated in the southeastern region, with approximately $85 \%$ of the national production, with São Paulo being the largest producer (IBGE 2018). Therefore, phytosanitary measures that prevent the introduction of this mite to these areas are necessary.

Ecological information on S. hindustanicus is scarce, and the true dispersal potential of this mite in Brazil is unknown. Although Roraima is responsible for only approximately $0.05 \%$ of the national citrus production (IBGE 2018), citrus cultivation has been expanding in recent years, and fruits have been sold in Amazonas, increasing the risks of dissemination. The objective of this study was to evaluate the distribution of $S$. hindustanicus in citrus in Roraima and to identify other mites associated with this species.

\section{Material and Methods}

A survey was conducted between August and September 2015 in all the 15 municipalities of the state of Roraima: Alto Alegre, Amajari, Boa Vista, Bonfim, Cantá, Caracaraí, Caroebe, Iracema, Mucajaí, Normandia, Pacaraima, Rorainópolis, São João da Baliza, São Luís, and Uiramutã. The main citrus orchards in the main producing regions of each municipality were inspected. The farms sampled were indicated by the technicians of Secretary of Agriculture, Livestock and Food Supply (SEAPA-RR) of each municipality. The area of orchards ranged from 0.5 to 10 ha, of citrus varieties. Citrus plants in backyards or public areas along main highways and in urban areas were also sampled.

In each field, producers were shown photos of attacked plants and asked about the presence of plants showing evidence of $S$. hindustanicus. Ten plants, distributed across the whole orchard in zig-zag sampling pattern, were inspected. All plants indicated by the producers showing possible evidence of mite attack were also sampled. The following data were collected for each collection point: geographical coordinates, planted area, number of plants, variety or varieties, age of plants, and use of acaricides. Ten leaves and ten fruits were collected from each plant, whether or not it had been attacked.

The collected leaves and fruits were placed in paper bags, labeled, and then packed in plastic bags. Samples were placed in a Styrofoam box, and at the end of the daily collections, they were sent to the Laboratory of Entomology of Embrapa Roraima, where they were inspected under a stereomicroscope ( $\times 40$ magnification). Those mites found were mounted on microscope slides using Hoyer's medium and then were sent to the Acarology Laboratory of the Luiz de Queiroz College of Agriculture, University of São Paulo, for species identification.

\section{Results}

\section{Distribution of S. hindustanicus}

Schizotetranychus hindustanicus was found in all the $15 \mathrm{mu}-$ nicipalities of the state of Roraima (Fig 1A), although it was not found at all collection points (Table 1). In Amajari, the mite was found in nine of the 11 sampled points at all points along the RR-203 highway and in the urban area (Fig 1B). In Pacaraima, the mite was found in 14 of the 30 sampled points (Table 1). In this municipality, $S$. hindustanicus was not found in the urban area (seat) but was found in Vila São Marcos, on the margin of highway BR 174, and in the villages of Surumu and Contão (Fig 1B). In Uiramutã, S. hindustanicus was found only at one out of 23 sampled points, close to the border with Guyana. In Normandia, the mite was also well dispersed, being found at 24 of the 29 


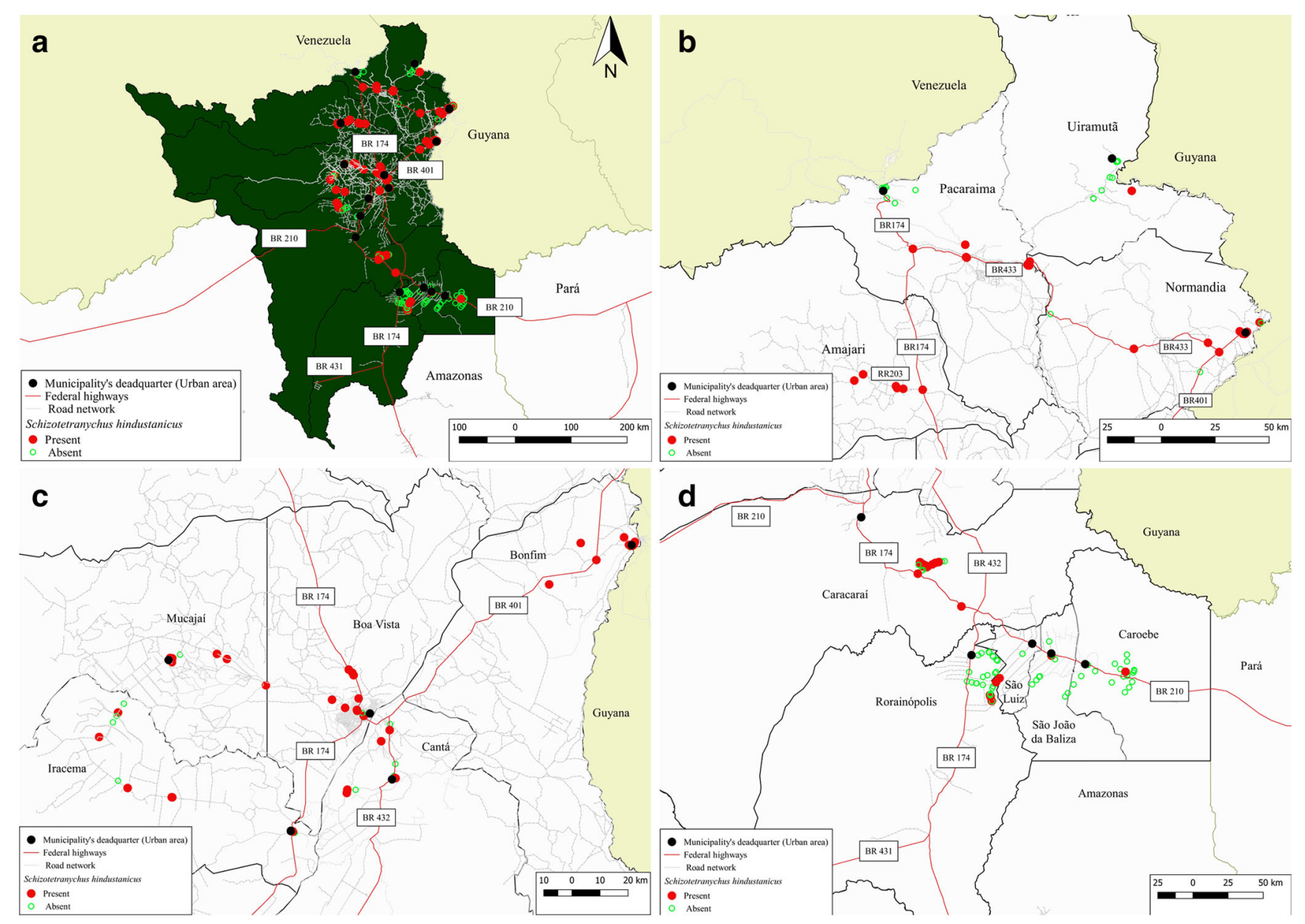

Fig 1 Spatial distribution of Schizotetranychus hindustanicus in Roraima (A), municipalities of the northern (B), central (C), and southern (D) regions of the state.

sampled points, including at the seat of the municipality and along roads (Table 1 and Fig $1 \mathrm{~B}$ ). The northern region of Roraima has no commercial citrus orchards, only small producers who have fewer than 20 fruit trees and occasionally sell the fruits in local markets.

In the central region of Roraima, S. hindustanicus was dispersed among practically all the sampled points, including in the seat of the municipalities, production areas, and roads (Fig $1 \mathrm{C}$ ). In the municipality of Alto Alegre, the mite was found at 10 of the 13 points sampled, including all points along highway RR-205 to the municipality and in the urban area of the city. In Boa Vista, the mite was found at all except two sampled points and was present throughout the urban area and in the commercial orchards of the Monte Cristo region. In Bonfim, S. hindustanicus was found at all 15 sampled points, both in the municipality seat and along the highway. In Cantá and Mucajaí, the mite was present at 7 of the 15 points sampled. In Iracema, the mite was found on the road near the border with Mucajaí and was not found at the municipality seat (Table 1 and Fig $1 C$ ).
In the south of the state, S. hindustanicus was widely dispersed in Caracaraí and was found in some citrusproducing areas in the other municipalities (Fig 1D). In 2015, the mite was possibly beginning to disperse into this region. According to IBGE (2018), the highest citrus production in Roraima is concentrated in the south of the state, especially in the municipalities of Rorainópolis, Caracaraí, and Caroebe (Table 1). Boa Vista was the municipality where the highest number of specimens of $S$. hindustanicus was found, followed by Pacaraima, Normandia, and Bonfim (Table 2).

\section{Mites associated with citrus in Roraima}

A total of 3518 specimens were found, representing two families of phytophagous mites (Tenuipalpidae and Tetranychidae), six families of predominantly predatory mites (Ascidae, Bdellidae, Blattisociidae, Cheyletidae, Cunaxidae, and Phytoseiidae), and two families with other feeding habits (Winterschmidtiidae and Oribatida) (Table 2). Phytophagous mites included S. hindustanicus and Brevipalpus yothersi Baker (Tenuipalpidae), the first being 
Table 1 Planted area and number of citrus establishments, number of points or orchards sampled, number of points where Schizotetranychus hindustanicus (Hirst) (Prostigmata: Tetranychidae) was present, and citrus varieties sampled and attacked by the mite in the municipalities of Roraima, Brazil.

\begin{tabular}{|c|c|c|c|c|c|c|}
\hline Municipality & $\begin{array}{l}\text { Planted } \\
\text { area } \\
\text { (ha)* }\end{array}$ & $\begin{array}{l}\text { Number of } \\
\text { establishments* }\end{array}$ & $\begin{array}{l}\text { Number of } \\
\text { sampled } \\
\text { points }\end{array}$ & $\begin{array}{l}\text { Points where } \\
\text { Schizotetranychus } \\
\text { hindustanicus was present }\end{array}$ & Varieties sampled & $\begin{array}{l}\text { Varieties attacked } \\
\text { by } \\
\text { S. hindustanicus }\end{array}$ \\
\hline Alto Alegre & 36 & 11 & 13 & 10 & $\begin{array}{l}\text { Pera orange, Key lime, tangerine, Ponkan } \\
\text { mandarin }\end{array}$ & All sampled \\
\hline Amajari & 12 & 21 & 11 & 9 & Pera orange, lime, lemon, Tahiti lemon & All except lime \\
\hline Boa Vista & 97 & 41 & 16 & 14 & $\begin{array}{l}\text { Citrus } \times \text { sinensis, Pera orange, Valencia } \\
\text { orange, Key lime, Tahiti lemon, } \\
\text { tangerine }\end{array}$ & All sampled \\
\hline Bonfim & 78 & 13 & 15 & 15 & $\begin{array}{l}\text { Pera orange, Key lime, Tahiti lemon, } \\
\text { Ponkan mandarin, tangerine }\end{array}$ & All sampled \\
\hline Cantá & 88 & 127 & 15 & 7 & $\begin{array}{l}\text { Citrus } \times \text { sinensis, Pera orange, Key lime, } \\
\text { Tahiti lemon, tangerine }\end{array}$ & $\begin{array}{l}\text { All except } \\
\text { tangerine }\end{array}$ \\
\hline Caracaraí & 118 & 60 & 28 & 21 & $\begin{array}{l}\text { Citrus } \times \text { sinensis, Pera orange, Valencia } \\
\text { orange, Key lime, Tahiti lemon, } \\
\text { tangerine }\end{array}$ & All sampled \\
\hline Caroebe & 124 & 92 & 37 & 1 & $\begin{array}{l}\text { Citrus } \times \text { sinensis, Pera orange, Valencia } \\
\text { orange, lime, Key lime, Tahiti lemon, } \\
\text { Ponkan mandarin }\end{array}$ & Only Pera orange \\
\hline Iracema & 25 & 22 & 14 & 4 & $\begin{array}{l}\text { Citrus } \times \text { sinensis, Pera orange, Valencia } \\
\text { orange, Key lime, Tahiti lemon, Ponkan } \\
\text { mandarin }\end{array}$ & $\begin{array}{l}\text { Pera orange and } \\
\text { Tahiti lemon }\end{array}$ \\
\hline Mucajaí & 61 & 76 & 15 & 7 & $\begin{array}{l}\text { Pera orange, Valencia orange, Key lime, } \\
\text { Tahiti lemon }\end{array}$ & $\begin{array}{l}\text { Pera orange and } \\
\text { Key lime }\end{array}$ \\
\hline Normandia & 0 & 2 & 29 & 24 & $\begin{array}{l}\text { Pera orange, Citrus aurantium, Key lime, } \\
\text { Tahiti lemon, Ponkan mandarin, } \\
\text { tangerine }\end{array}$ & All sampled \\
\hline Pacaraima & 0 & 2 & 30 & 14 & $\begin{array}{l}\text { Pera orange, lime, Key lime, Tahiti lemon, } \\
\text { Ponkan mandarin, tangerine }\end{array}$ & $\begin{array}{l}\text { Pera orange, Key } \\
\text { lime and Tahiti } \\
\text { lemon }\end{array}$ \\
\hline Rorainópolis & 744 & 389 & 30 & 4 & $\begin{array}{l}\text { Bahia orange, Pera orange, Pera } \\
\text { orange-rio, Tahiti lemon }\end{array}$ & Pera orange \\
\hline $\begin{array}{l}\text { São João da } \\
\text { Baliza }\end{array}$ & 27 & 28 & 14 & 1 & Pera orange, Tahiti lemon, citron fruit & Pera orange \\
\hline São Luiz & 45 & 53 & 3 & 2 & Pera orange & Pera orange \\
\hline Uiramutã & 2 & 5 & 23 & 1 & $\begin{array}{l}\text { Pera orange, lime, Key lime, Tahiti lemon, } \\
\text { Ponkan mandarin, tangerine }\end{array}$ & Key lime \\
\hline Total & 1459 & 942 & 292 & 133 & - & - \\
\hline
\end{tabular}

*Agricultural establishments with 50 plants or more, according to IBGE (2018)

more abundant (Table 2). Phytoseiidae was predatory family most abundant, with fourteen observed species. Amblyseius aerialis (Muma) was the most abundant species, followed by Euseius concordis (Chant) and Iphiseiodes zuluagai Denmark and Muma. The municipality where Phytoseiidae was more abundant is Caroebe (Table 2).

\section{Discussion}

The results of this study show that $S$. hindustanicus has been spreading in Roraima in recent years, increasing the risk of this pest reaching the main citrus-producing regions in Brazil. Although the current legislation allows fruits grown in
Roraima to be traded in other states after being treated according to current legislation (MAPA 2012), a risk exists for plants or plant parts infested by $S$. hindustanicus being transported informally. Within the state, no phytosanitary measures exist to prevent the dispersal of $S$. hindustanicus by human action. Short-distance dispersal, caused by wind, may also occur.

In Venezuela, S. hindustanicus also has been spreading over the years. After the first report in Zulia in the northwest of the country, where the mite has been found since the late 1990s (Quirós \& Geraud-Pouey 2002), the mite also was reported in Sucre in the northeast, and in central areas, such as Aragua (Nienstaedt \& Marcano 2009, Ferragut 2013). In Colombia, since its detection in the northern coast of the country, in the state of La Guajira (Mesa-Cobo 2010), there 
Table 2 Mites associated with citrus collected in Roraima in August and September of 2016.

\begin{tabular}{|c|c|c|c|c|c|c|c|c|c|c|c|c|c|c|c|c|}
\hline \multirow[t]{2}{*}{ Taxon } & \multirow[t]{2}{*}{ Total } & \multicolumn{15}{|c|}{ Municipality* } \\
\hline & & AA & AM & BV & $\mathrm{BO}$ & $\mathrm{CT}$ & $\mathrm{CC}$ & $\mathrm{CR}$ & IR & MU & NO & PA & RO & SJ & $\mathrm{SL}$ & UI \\
\hline \multicolumn{17}{|l|}{ Phytophagous } \\
\hline \multicolumn{17}{|l|}{ Tenuipalpidae } \\
\hline Brevipalpus yothersi Baker & 41 & & & & & & & & & & 41 & & & & & \\
\hline \multicolumn{17}{|l|}{ Tetranychidae } \\
\hline Schizotetranychus hindustanicus (Hirst) & 3,290 & 24 & 217 & 774 & 553 & 139 & 5 & 12 & 286 & 32 & 529 & 689 & 9 & 9 & 3 & 9 \\
\hline \multicolumn{17}{|l|}{ Predatory } \\
\hline \multicolumn{17}{|l|}{ Ascidae } \\
\hline Asca sp. & 1 & & & & & & & & & & 1 & & & & & \\
\hline \multicolumn{17}{|l|}{ Bdellidae } \\
\hline Bdella sp. & 2 & 1 & & & & & & & 1 & & & & & & & \\
\hline \multicolumn{17}{|l|}{ Blattisociidae } \\
\hline Lasioseius sp. & 1 & & & & 1 & & & & & & & & & & & \\
\hline \multicolumn{17}{|l|}{ Cheyletidae } \\
\hline Cheletogenes ornatus (Canestrini and Fanzano) & 4 & & & & & & & & & & & 4 & & & & \\
\hline Cunaxidae & 3 & & & 3 & & & & & & & & & & & & \\
\hline Phytoseiidae & 98 & 0 & 6 & 3 & 5 & 1 & 15 & 38 & 2 & 5 & 12 & 5 & 3 & 2 & 0 & 1 \\
\hline Amblydromalus sp. & 1 & & & & 1 & & & & & & & & & & & \\
\hline Amblyseius aerialis (Muma) & 24 & & & & 2 & 1 & & 14 & 1 & 1 & 4 & 1 & & & & \\
\hline Amblyseius acalyphus Denmark and Muma & 2 & & & & & & 1 & 1 & & & & & & & & \\
\hline Amblyseius chiapensis De Leon & 12 & & 2 & & & & 4 & & & 1 & 4 & 1 & & & & \\
\hline Amblyseius aff. fernandezi Chant and Baker & 12 & & 2 & & 1 & & 4 & & & & 4 & 1 & & & & \\
\hline Amblyseius largoensis (Muma) & 4 & & & & & & 2 & 2 & & & & & & & & \\
\hline Amblyseius tamatavensis Blommers & 3 & & 1 & & & & & 1 & & & & 1 & & & & \\
\hline Euseius alatus De Leon & 1 & & & & & & 1 & & & & & & & & & \\
\hline Euseius citrifolius Denmark and Muma & 2 & & & 2 & & & & & & & & & & & & \\
\hline Euseius concordis (Chant) & 16 & & & & & & 1 & 13 & & & & & & 2 & & \\
\hline Galendromus (Galendromus) annectens (De Leon) & 4 & & & & & & 1 & & & & & & 3 & & & \\
\hline Iphiseiodes zuluagai Denmark and Muma & 13 & & 1 & & & & 1 & 6 & 1 & 2 & & 1 & & & & 1 \\
\hline Proprioseiopsis neotropicus (Ehara) & 3 & & & 1 & 1 & & & & & 1 & & & & & & \\
\hline Typhlodromus (Anthoseius) ornatus (Denmark and Muma) & 1 & & & & & & & 1 & & & & & & & & \\
\hline \multicolumn{17}{|l|}{ Other feeding habits } \\
\hline \multicolumn{17}{|l|}{ Winterschmidtiidae } \\
\hline Czenspinskia transversostriata Oudemans & 10 & & & & & & & & & & & 10 & & & & \\
\hline Oribatida & 68 & & 9 & 6 & 3 & & 1 & 9 & 18 & & 18 & 2 & 1 & 1 & & \\
\hline Total & 3,518 & 25 & 232 & 786 & 562 & 140 & 21 & 59 & 307 & 37 & 601 & 710 & 13 & 12 & 3 & 10 \\
\hline
\end{tabular}

* $A A$, Alto Alegre; $A M$, Amajari; $B V$, Boa Vista; $B O$, Bonfim; $C T$, Cantá; $C C$, Caracaraí; $C R$, Caroebe; IR, Iracema; $M U$, Mucjaí; NO, Normandia; $P A$, Pacaraima; $R O$, Rorainópolis; SJ, São João de Baliza; SL, São Luís; UI, Uiramutã

were other reports of its occurrence in the Department of Magdalena in 2011 in the northern region and in 2012 in the southern region of the department (Arévalo et al 2012).

Since the mite's description in 1924 (Hirst 1924), a few studies on S. hindustanicus have been published on its possible center of origin (India), but more recently, this mite was again reported in Podavur, India (Poorani 2018), $200 \mathrm{~km}$ east of Coimbatore. In 2010, S. hindustanicus was also reported in Iran (Sheikholeslam-Zadeh \& Sadeghi-Nameghi 2010).
Possibly, this mite is present in other locations in these regions but at low densities or misidentified as other species of the same genus (Ferragut et al 2013).

Schizotetranychus hindustanicus was more abundant and dispersed in the northern and central regions of Roraima, where the biome Cerrado is predominant and drier than in the south of the state (Amazon rainforest) (Barni et al 2015). The population of this mite is negatively affected by rainfall (Nienstaedt \& Marcano 2009). The low density and 
distribution of this mite in the southern municipalities can be related to the longer rainy seasons (7-11 months) and higher annual average rainfall $(2,000-2,300 \mathrm{~mm})$ than in the Cerrado (5-6 months of rainy season and 1100$1400 \mathrm{~mm}$ year $^{-1}$ ) (Barni et al 2015; Barni et al 2016). In fact, studies conducted in Caracaraí (unpublished) indicate very low densities of $S$. hindustanicus during the rainy season.

Few studies have been conducted on the predators associated with S. hindustanicus. Marsaro Jr et al (2012) observed the predators E. concordis and I. zuluagai and Galendromus annectens (De Leon) (Phytoseiidae) in a Tahiti lemon plantation attacked by S. hindustanicus in Boa Vista, Roraima, with E. concordis being the most abundant predator. In India, Stethorus (Allostethorus) forficatus Poorani and Stethorus tetranychi Kapur (Coleoptera: Coccinellidae) spider mites were reported as efficient predators in the control of S. hindustanicus (Poorani 2018). In their classification of phytoseiid lifestyles, McMurtry et al (2013) classified those mites that specialize in attacking the tetranychids that produce a nest-like web as "predators of subtype lb," specifically mentioning the phytoseiid Typhlodromus (Anthoseius) bambusae (Ehara) as an efficient control agent of Schizotetranychus celarius (Banks) in China. A single specimen of this genus was found in the present study: Typhlodromus (Anthoseius) ornatus (Denmark and Muma).

Amblyseius aerialis has been reported in the Amazon region in association with Citrus sp. in the states of Amapá (Mineiro et al 2009) and Amazonas (Bobot et al 2011; Ferreira et al 2018). This predator has also been found on other plants in the Amazon, such as Hevea spp. in the states of Acre, Amazonas, and Rondônia (Nuvoloni et al 2015); Cocos nucifera in Amazonas (Cruz et al 2015), Pará (LawsonBalagbo et al 2008), and Roraima (Gondim Jr et al 2012); and in several other plants (Demite et al 2018). In Amazonas, A. aerialis was reported as the most abundant predator with potential for control of the leprosy mite, $B$. yothersi (Ferreira et al 2018). This phytoseiid, with E. concordis and I. zuluagai, may also be potential candidates for the biological control of S. hindustanicus, and complementary studies should be conducted to assess its predatory impact on this pest.

Author's Contribution EGF planned and designed the study and wrote the manuscript. FLF collected field data and wrote the manuscript. RS Pereira analyzed the samples in laboratory and mounted the microscope slides. JCS identified the mites. DCO collected field data. MN constructed the distribution maps. GJM identified the mites and reviewed the manuscript. All authors read, revised, and approved the manuscript.

Funding Information This study received financial support from Embrapa and the Brazilian National Council for Scientific and Technological Development (CNPq).

\section{References}

Arévalo E, Delgado L, González M (2012) Situación actual de Ácaro hindú de los cítricos Schizotetranychus hindustanicus (Hirst) (Prostigmata: Tetranychidae) en Colombia (Boletín epidemiológico). Instituto Colobiano Agropecuario. https://www.ica.gov.co/Areas/Agricola/ Servicios/Epidemiologia-Agricola/BOLETINES/Nacionales/2012/B_N_ SHINDUSTANICUS_DIC_2012.aspx. Accessed 01 Oct 2018

Barni PE, Pereira VB, Manzi AO, Barbosa RI (2015) Deforestation and forest fires in Roraima and their relationship with phytoclimatic regions in the Northern Brazilian Amazon. Environ Manag 55:11241138

Barni PE, Manzi AO, Condé TM, Barbosa RI, Fearnside PM (2016) Spatial distribution of forest biomass in Brazil's state of Roraima, northern Amazonia. For Ecol Manag 377:170-181

Bobot TE, Franklin E, Navia D, Gasnier TRJ, Lofego AC, Oliveira BM (2011) Mites (Arachnida, Acari) on Citrus sinensis L. Osbeck orange trees in the state of Amazonas, Northern Brazil. Acta Amazon 41(4):557-566 Cherian MC (1931) South Indian Acarina. J Asiatic Soc Beng 27:141-147

Citros-BR (2018). Associação Nacional de Exportadores de Sucos Cítricos. http://www.citrusbr.com/mercadoexterno/?me=01. Accessed 02 Oct 2018

Cruz WP, Krug C, Vasconcelos GJN, Moraes GJ (2015) Diversity of mites associated with Raoiella indica (Acari: Prostigmata) on coconut palms in the central region of the Brazilian Amazonia, with emphasis on the predaceous Phytoseiidae (Acari: Mesostigmata). Syst Appl Acarol 20(8):875-886

Demite PR, Moraes GJ, Mcmurtry JA, Denmark HA, Castilho RC (2018) Phytoseiidae database. www.lea.esalq.usp.br/phytoseiidae. Accessed 08 Oct 2018

Fantine A (2011) In: 204 f. Dissertation - Universidade Federal de Viçosa (ed) Schizotetranychus hindustanicus (Hirst, 1924) (ACARI: TETRANYCHIDAE): rotas de risco e potencial de impacto para a citricultura brasileira

Ferragut F, Navia D, Ochoa R (2013) New mite invasions in citrus: a look towards the early years of the twenty-first century. Exp Appl Acarol 59(1-2):145-164

Ferreira CT, Krug C, Garcia MVB, De Moraes GJ (2018) Leprosis mite and other mite species (Acari) associated to orange groves in Brazilian Central Amazon. Syst Appl Acarol 23(3):449-462

Gondim MGC Jr, Castro TMMG, Marsaro A Jr, Navia D, Melo JWS, Demite PR, Moraes GJ (2012) Can the red palm mite threaten the Amazon vegetation? Syst Biodivers 10(4):527-535

Gupta SK, Gupta YN (1994) A taxonomic review of Indian Tetranychidae (Acari: Prostigmata) with description of new species, redescriptions of known species and keys to genera and species. Mem Zool Surv India 18:1-196

Hirst S (1924) On some new species of red spider. Ann Mag Nat Hist 14: 522-527

IBGE (2018) Censo Agropecuário:2017 https://sidra.ibge.gov.br/ pesquisa/censo-agropecuario/censo-agropecuario-2017. Accessed 01 Oct 2018

Lawson-Balagbo LM, Gondim MGC Jr, Moraes GJ, Hanna R, Schausberger $P$ (2008) Exploration of the acarine fauna on coconut palm in Brazil with emphasis on Aceria guerreronis (Acari: Eriophyidae) and its natural enemies. Bull Entomol Res 98:83-96

MAPA (2012) Sanidade animal e vegetal. http://www.agricultura.gov.br/ assuntos/sanidade-animal-e-vegetal/sanidade-vegetal/arquivosprevencao/copy_of_IN8_2012caroHindu.pdf. Accessed 25 Sep 2018

Marsaro A Jr, Sato ME, Aguiar RM, Vieira GB, Silva RJ Jr, Mineiro JLC (2012) efeito de acaricidas sobre schizotetranychus hindustanicus (hirst) (acari: tetranychidae) e ácaros predadores em citros no estado de roraima, brasil. Arq Inst Biol 79(1):75-83 
Mcmurtry JA, Moraes GJ, Sourassou NF (2013) Revision of the lifestyles of phytoseiid mites (Acari: Phytoseiidae) and implications for biological control strategies. Syst Appl Acarol 18 (4): 297-320.

Mesa-Cobo NC (2010) Ácaros asociados a cítricos em Colombia. http:// www.asohofrucol.com.co/archivos/biblioteca/biblioteca_60_\%C3\% 81caros\%20asociados\%20a\%20C\%C3\%ADtricos\%20en\%20Colombia. pdf. Accessed 01 Oct 2018

Migeon A, Dorkeld F (2018) Spider mites web: a comprehensive database for the Tetranychidae. http://www.montpellier.inra.fr/CBGP/ spmweb. Accessed 08 Oct de 2018

Mineiro JC, Silva WR, Silva RA (2009) Ácaros em fruteiras e outras plantas no Estado do Amapá. Biota Neotrop 9(2):103-106

Navia D, Marsaro A Jr (2010) First report of the citrus hindu mite, Schizotetranychus hindustanicus (Hirst) (Prostigmata: Tetranychidae), in Brazil. Neotrop Entomol 40(3):140-143

Nienstaedt B, Marcano R (2009) Fluctuación poblacional y distribución vertical del ácaro Schizotetranychus hindustanicus (Hirst, 1924), sobre especies de Citrus. Entomotropica 24(2):57-63

Nuvoloni FM, Lofego AC, Rezende JM, Feres RJF (2015) Phytoseiidae mites associated with Hevea spp. from the Amazon region: a hidden diversity under the canopy of native trees. Syst Biodivers 13(2):182206
Poorani J (2018) Stethorus spp. (Coleoptera: Coccinellidae) predatory on Schizotetranychus hindustanicus (Hirst) (Acari: Tetranychidae) from South India, including a new species and a new synonymy in Indian Stethorus. Zootaxa 4277(4):591-599

Quirós M, Geraud-Pouey F (2002) Schizotetranychus hindustanicus (Hirst) (Acari: Tetranychidae), new spider mite pest damaging citrus in Venezuela, South America. In: Morales-Malacara JB, Rivas G (eds) $\mathrm{XI}$ international congress of acarology. Program and abstract book. Universidad Nacional Autónoma de México, Mexico City, pp 255-256

Quirós M, Dorado I (2005) Eficiencia de tres productos comerciales en el control del ácaro hindú de las cítricas Schizotetranychus hindustanicus (Hisrt), en el laboratorio, Abstract 183. In Congreso de Entomología 2005. Universidad del Zulia, Maracaibo.

Sheikholeslam-Zadeh S, Sadeghi-Nameghi H (2010) First records of four mite species (Acari: Tetranychidae) in Iran. Appl Entomol Phytopathol 78:121-125

Publisher's Note Springer Nature remains neutral with regard to jurisdictional claims in published maps and institutional affiliations. 